\title{
Onomastic Perspective On Java Communities Based On Social Stratification
}

\author{
Eddy Sugiri ${ }^{1}$, Dwi Handayani ${ }^{2}$, Muchtar Lutfi ${ }^{3}$ \\ \{1 eddys.unair, ${ }^{2}$ dwihanda1967@yahoo.co.id, ${ }^{3}$ mochtar_lutfi@yahoo.com $\}$ \\ Universitas Airlangga
}

\begin{abstract}
The purpose of this study is to describe the onomastic perspective of Javanese society based on its social stratification. The population in this study is the Javanese people who live in the East Java Province. Social stratification based on education, religion, and residence (area). The method used in this research is descriptive qualitative method. Meanwhile, the method of data collection uses random sampling with structured interview techniques. This interview was also recorded using a cellular telephone. The results of this study indicate that in giving names to children, Javanese people who are Muslim often use Arabic and important events in the Islamic religion. Meanwhile, many Christians take from Italian and Hebrew, as well as from important events in Christian Religion. Javanese people who are highly educated often give names to their children by using the name of a hero, a combination of Javanese and Arabic, and dominant sounds [a]. Whereas the names of Javanese people with low education generally take names according to local or regional names derived from Javanese. and dominant sounds [o], [nem], [min], and [yah]. This is almost the same as the name of the Javanese people who live in the village.
\end{abstract}

Keywords: onomastics, Javanese society, social stratification

\section{Introduction}

For people who believe that Adam was the first human being on this earth, they certainly believed that the use of language began when Adam named the things created by God. The Quran clearly proves this statement. 'Allah taught Adam all the names of the objects to the angels while saying,' Tell me the names of these things if you are right. They answered, 'Glory be to you, O God, we do not know, but what you teach us, indeed you know wisely.' in Quran, Surah Albaqarah verses 31-32.

From the above quotation, two essential things can be seen in this study. First, God the Creator of the universe taught the first human being the knowledge of the naming of objects and creatures that He created, Adam. Second, humans are given the opportunity and ability to name everything because $\mathrm{He}$ is more powerful over all things and creatures among His creations on this earth.

Onomastics is "the science or study of the origin and forms of proper names of persons or places" meaning "study of the origin and form of names of people or places" (Webster's Dictionary, https: //www.merriam- webster.com/ dictionary/onomastics). Potter says that in 
the early stages of language history, the first known words were names [1]. According to Potter, people have long been aware of the close relationship between names and the object of reference between names and people who own them. Anglo-Saxson society, for example, has always held to the principles from generation to generation in giving names to their children.

So important is the meaning of the name for the owner, everyone will feel annoyed if the name is written or pronounced incorrectly. All civilized humans are aware of the truth of this fact. That is why traditional and formal punishment is so severe for anyone who misuses the name of another person.

A novelist or director often writes at the beginning of his work "Names and events in this work are fictitious and not imitations in the name of an actual person or event." Famous poet Shakespeare who lived in 1564-1616 is said to have asked "What is a name ? "No one knows for sure what exactly is behind the sentence, especially because the sentence was expressed by a great poet who had triumphed on this earth.

In line with the differences in social status (including education, position / position, economy, religion / religious beliefs, and gender) for the Javanese people, the perspective in the process of giving a name is naturally varied. Research on topics like this has never been done by anyone else. Therefore, research with the topic Perspective Onomastik in Javanese Communities Based on Social Stratification Ethnolinguistic studies very important because the results of this study can be used as a guide for ethnic Javanese in giving names to their children.

\section{Research Method}

The method used in this research is a descriptive qualitative method with random sampling data collection techniques accompanied by free and structured interviews using instruments in the form of questionnaires. This interview was also recorded using a cellular telephone. The results of the recording will be used as material to confirm the results of the interview notes to improve data accuracy. The information extracted revolved around the perspective of the process of giving names and the meaning of names from (a) the level of religion, (b) education, (c) the area or region of residence.

The object of this research is Javanese people living in Java. In this study, Javanese people are interpreted as native speakers of Javanese, live in Javanese society, and have Javanese parents [2]

\section{Results And Discussion}

In everyday relationships, we will have difficulty if someone does not have a name or nickname. We cannot call or greet him. It has become a habit of the community if someone whose name is unknown is identified according to the characteristics that exist in him, for example Mr. Mustache because he has a thick mustache, the Hunchback because his back is not straight (remember there is the title of the film "The Hunchback of the Ghost Cave"), etc.

The name or onomastics problem has existed since $700 \mathrm{BC}$. This naming changes with the times as cultural changes from the form of work of Rome to the Republic, the entry of Greek culture, the entry of Christianity, weak legal control [3]. Traditional culture and colonization also helped determine the community's naming system. Barret Robb [4], states the procedure 
for naming children in the Scottish community based on traditional methods by naming the first child based on the name of the father of the biological father, the name of the second child based on the name of the mother of the biological father and so on. But with the migration of people to other places (migration to America) the name was changed. However, in the Scottish community who live in America, this pattern is still used.

Names when observed, not only the names of objects or events that change, however, new names always appear from time to time [5]. Tarigan [6] says that a name is given to someone to distinguish it from others; to make it easier for family / community members to call him and tell him if necessary. Names are made to be used, to be called, for the sake of practicality in everyday life.

Giving a name or onomastis has two functions, namely (a) to give and strengthen the identity of its people, and (b) to strengthen the trust of its people [7]. Because basically names can be used as a term to refer to anything, the naming process is often considered to be human-like or arbitrary [8]. To overcome this omnipresentity, in real communication it is necessary to refer to the context that is related to the expression of the name. However, not all aspects related to naming are manasuka. In some cases, the naming is systematic. One proof of this systematicism is the relationship between names and gender, almost all names in language have gender implications [9]. Second, in a number of languages, the 'vocabulary' for names seems to have been limited, such as names in English that are relatively tightly arranged, even have been condemned [10]. Third, the naming system in certain societies has been so bound by relatively rigid rules, because one must bear certain names based on birth order for example, as happened to the Buang community [11] or Bali [12]. In certain languages, names actually have semantically significant meanings, as is often the case in Javanese society. From the description above it is clear that each culture system has its own naming system. Giving a name in a community seems to be very colored by the socio-cultural system adopted by the community. For example, names given to children of Anglo-Saxon ancestry (given names, not inherited family names) are strongly colored by the color of local culture, especially the nuances of Christianity [13]. Another example, ethnic Malay names are strongly colored by Arabic, which was introduced through the spread of Islam.

Aribowo [14] in his research stated that there was a shift in the choice of children's names in the Javanese community environment in the Klaten area, from Javanese names to Arabic names, in line with the shift in information and local culture.

\subsection{Onomastic Perspectives on Javanese Communities from the Realm of Religion}

\subsubsection{Onomastic Perspectives on Javanese Communities from the Realm of Islamic Religion}

Stratification from the realm of the Islamic religion can be found that the origin of the name in the CommunitySome Javanese who are Muslim are from Arabic, Indonesian is combined with Arabic, and some are from Javanese combined with languages Arab.

Ahmad Dzakiandra Al Ghifari is a name from the Arabic language which means that Dzakiandra means 'intelligent child' while, Al Ghifari means 'forgiving'. So, parents hope that one day their children will become 'intelligent and forgiving' people.

Fauziah Bahamarianti Fajiroh is a name from Arabic and a combination of parents 'names that means fauziah means' victory ', bahamarianti means' a combination of the names of both parents 'and fajiroh' means the birth time of 'dawn'. So, Fauziah Bahamarianti Fajiroh means giving meaning 'memories at birth at dawn, which is in the morning around 04.00 05.30 WIB. 
Haibatul Iftinah Al Azhariya is the name of the Arabic language which has the meaning of al Azhariyah meaning 'flower / flowers' while, haibatul iftinah means 'magnificent and beneficial'. So, parents hope that one day their children will become people taman like a beautiful / magnificent and meaningful / useful flower garden '.

Muhammad Hanif Abdillah is a name from the Arabic language which means that Muhammad means 'boy', hanif means 'graduated / correct', whereas, abdillah means 'servant of Allah SAW'. So, parents hope that one day their children will become people 'who have the right behavior as exemplified by the Prophet Muhammad SAW'.

Achmad Zain Al Idris is the name of the Arabic language which means 'flower / flowers', while, haibatul iftinah means 'magnificent and beneficial'. So, parents hope that one day their children will become people taman like a beautiful / magnificent and meaningful / useful flower garden'.

\subsubsection{Onomastic Perspective on Javanese Communities from the Realm of Christianity}

Stratification from the realm of Christianity can be found that the origins of names in Javanese Christians are derived from Italian, Indonesian, Hebrew, Latin, Greek, religious events, and some are derived from the name of the month and place, as well as baptismal names [15].

Fina Widayanti is the name of the Italian language and Javanese language which has the meaning fina is an abbreviation of Seafina (Santa Serafina) 'woman who never gives up and perseveres' whereas, widayanti means 'woman of knowledge'. So, parents hope that one day their children will become women who are diligent in seeking knowledge.

Gebya Greciolla is the name of the Italian language which means greciolla has the meaning 'generosity (generosity from God)' while, the word gebya means 'grace'. So, the hope of parents so that one day their children become people / individuals who always get generosity and grace from God.

Jeremiah Renaldy Joelianto is the name of Hebrew, Latin, Italian, Greek, Javanese. Jeremiah is a baptismal name which means 'glorify God' whereas, the word renaldy means 'wise ruler'. The word Julianto takes the name of the month of birth which is July. So, parents hope that one day their child born in July will be a person / person who always glorifies the name of God and becomes a wise official / ruler. The word yulianto was given by a midwife who helped Jeremiah Renaldy Joelianto in labor.

Natalia Purwanti is a name that takes from Christian religious events which is Christmas. Meanwhile, Purwanti from the word in Javanese Pur from the word purwo which means 'first'. So, Natalia Purwanti means 'The first girl born at Christmas.

\subsection{Onomastic Perspectives on Javanese Communities from the Educational Domain}

Stratification from the realm of education can be found that the origins of names in the Javanese community are taken from the names of figures or heroes, are from Arabic, Indonesian is combined with Arabic, and some are from Javanese combined with Arabic.

Soetomo, this name was taken from the name of a hero from Surabaya who at that time fought on November 10, 1945, which was called Heroes' Day. Thus, parents hope that 'the child named Soetomo has the character of a hero Soetomo'.

Haekal Rheza Afandi is the name of the Arabic / Islamic language. The word haekal means 'amulet' whereas, the word rheza means ahagiaan happiness '. The word afandi is taken from the names of male parents or family members who resemble clan names in other ethnicities. So, the parents hope that someday the son of Mr. Afandi becomes a person / person 'like a talisman who always gets happiness'. 
Suharto, this name was taken from Sanskrit and Javanese. Su means 'good' and harto means 'wealth or money'. So, Suharto meant 'his son would become a good and rich person'.

\subsection{Onomastic Perspectives on Javanese Communities from the Realm of Residence}

Budiman Airlangga is the name of the name of the figure or king of East Java (Kediri). So, Budiman Airlangga means 'children born have good character or behavior like the king of Airlangga.

Sujaka is the name of the Javanese community in the city with the dominant sound [a]. Sujaka means 'a good single man'.

Sujoko is the name of the Javanese community from the village. The dominant name sounds [o]. Sujoko means 'a good single man'.

Legimin is the name of the Javanese community from the village. Legi is taken from the market day of birth, which is 'legi', while min is used for men's names. So Legimin means 'boy born on the Legi market day'. While the name for the woman are Leginten or Legiyem. So, in the ethnic Javanese the last part is the name of the woman from the village or who has a low stratification using the syllable yem, nem, or yah [16].

\section{Conclusion}

From the results of data analysts, it can be concluded that Javanese people give names to their children in various ways depending on their social stratification. There are those who give their children names from Arabic, Itaia, Hebrew, and some even take names from figures or heroes and important events.

\section{References}

[1] Webster's Dictionary, https: //www.merriam- webster.com/dictionary/onomastics.

[2] Anderson, J.W.M. The Grammar of Name. Oxford: Oxford University Press, 2007.

[3] Salway, Benet. "What's in a Name? A Survey of Roman Onomastic Practice From c.700.B.C. to A.D. 700". The Journal of Roman Studies, Vol 84 (1994), pp 124-145, 2015.

[4] Casmir, Fred L. Interaction: An Introduction to Speech Communication. Ohio: Charles E. Meril Publish in Company, 1974.

[5] Djaya Sudarma, T. Fatimah. Semantik. Bandung: Fakultas Sastra, 1988.

[6] Echols, John M. dan Hassan Shadily. Kamus Inggris-Indonesia. Jakarta: PT. Gramedia, 2000.

[7] Finoza, Lamuddin. Komposisi Bahasa Indonesia untuk Mahasiswa Nonjurusan Bahasa. Jakarta: Diksi Insan Mulia, 2017.

[8] Garna, Judistira K. Teori-teori Perubahan Sosial. Bandung: Program Pascasarjana UNPAD, 1992.

[9] Garna, Judistira K. Ilmu-Ilmu Sosial: Dasar-Konsep-Posisi. Bandung: Program Pascasarjana UNPAD, 1996.

[10] Harris, Roy and Tablot J. Tailor. Landmarks in Linguistic Thought: The Western Tradition from Socrates to Saussure. London: Routledge, 1989.

[11] Panggabean, Himpun. Makna Nama dalam Masyatakat Batak Toba. Bandung: Bumi Siliwangi, 2015.

[12] Kesuma, Tri Mastoyo Jati. Pengantar Metode Penelitian Bahasa. Yogyakarta Carasvatibooks, 2007.

[13] Pusat Bahasa Depdiknas. Kamus Bahasa Indonesia. Jakarta: Pusat Bahasa, 2008.. 
[14] Aribowo, Eric Kunto, dan Nanik Herawati. "Trends in Naming System on Javanese Society: A Shift from Javanese to Arabic". Lingua Cultura, Vol.10 No.2, November 201 '6, 118-122, 2016.

[15] Rohmadi, Muhammad dkk. Belajar Bahasa Indonesia Upaya Terampil Berbicara dan Menulis Karya Ilmiah. Surakarta: Cakrawala Media, 2019.

[16] K. Saddhono, "Language of Coastal Communities in the Northern Coast of Central Java: Sociolinguistic Studies in Cultural Integration Maritime-Agrarian Perspective." Adv. Sci. Let. vol. 23 no. 10 pp 10054-10056, 2017 